\title{
Depression: Personality and Gender towards Alcohol Drinking Attitude
}

\author{
Dr Thiyam Kiran Singh ${ }^{1}$, Nishtha Kumar $^{2}$
}

\section{ABSTRACT}

The main purpose of the research was to study the relationship between the personality characteristics and gender on attitude towards alcohol drinking of the patients who has depression. The study utilized a 2x2 design. The sample population was Ninety which comprised of Females and Males and all were patients diagnosed as depression. The samples were collected from Delhi, Ahmedabad and Mumbai using purposive sampling method. Patients who fulfilled inclusion criteria were administered McCroskey Introversion scale (1997) and based on the scoring, sample population was divided into two groups: 1. Introverts and 2. Extroverts people. Scoring high on the test was classified as introverts and patients who score low on the test were classified as extroverts. Further classification was done as introvert males, introvert females, extrovert males and extrovert females. Scale measuring Attitude Towards Alcohol by B.R Bharda and P.R Girija(1983) was administered on all four groups of sample population. Analysis was done by using 2- way Analysis of Variance. The study found significant difference of Personality Characteristics (Introversion \&Extroversion) on Attitude towards alcohol and also significant difference of Gender (male \&female) on Attitude towards alcohol which conclude that extrovert personality has negative attitude towards drinking alcohol whereas introvert personality has positive attitude towards drinking alcohol. Again, the study also proclaim that female has negative attitude towards drinking alcohol where as male has positive attitude towards drinking alcohol.

Keywords: Personality, Gender, Attitude, Depression, Alcohol.

Depression is a major mental health concern during emerging adulthood Occurrence of depression is more of a presenting problem at an earlier stage in life. Personality refers to individuals' unique and relatively stable patterns of behavior, thoughts and feelings have put it, the psychological forces that make people uniquely themselves. According to Census, Depression is a disorder of major public health importance, in terms of its prevalence and the

\footnotetext{
${ }^{1}$ Associate Professor (Clinical Psychology), Government Medical College \& Hospital, Chandigarh, India

${ }^{2}$ M.Phil (Clinical Psychology) Trainee, Government Medical College \& Hospital, Chandigarh, India *Responding Author

(C) 2016 I T Singh, N Kumar; licensee IJIP. This is an Open Access Research distributed under the terms of the Creative Commons Attribution License (http://creativecommons.org/licenses/by/2.0), which permits unrestricted use, distribution, and reproduction in any Medium, provided the original work is properly cited.
} 
suffering, dysfunction, morbidity and economic burden. Depression is more common in women than men. It is estimated that by the year 2020 if current trends for demographic and epidemiological transition continue, the burden of depression will increase to $5.7 \%$ of the total burden of disease and it would be the second leading cause of disability-adjusted life years, second only to ischemic heart disease. It has also been seen that due to depression many people have got addicted to various kinds of substance abuse. In India depression is the second largest disorder consisting on $80 \%$ of the population after Cancer. Lynch gave the following comparison of Jung's concepts of extraversion and introversion: extraverts (Es) like variety and action; introverts (Is) like quiet for concentration. The Es tend to be faster and dislike complicated procedures, whereas is tend not to mind working on one project for a longtime without interruption. The Es are often good at greeting people and like having people around; the IS like to work contentedly alone and may often have difficulty remembering people's names and faces. Extraverts are interested in the results of their jobs, in getting it done and in how other people do it. Introverts, i.e. the other hand, are more interested in the idea behind the job. In addition to grouping people into two large groups, introversive and extroversive, Jung maintained that closer examination of individuals indicated that they also differed according to basic psychological functions Jung postulated that the extroversive type personality focused attention on external objects and was concerned with relations to other people. The introversive type personality focused on internal psychological processes and was concerned with pursuing solitary activities. Previous studies have examined aspects of Personality types and gender and also the effects of both on circumstances leading to alcoholism and especially in the state of depression. In this study, the Independent variables are personality types (Introversion) (Extroversion) and Second Independent variable is Gender and Dependent variable is attitudes towards drinking alcohol. The findings of this study will have several implications for mental health practitioners, educators and researchers, as the findings of current study will shows which gender and personality characteristic have a positive attitude towards alcohol specially under stressful conditions and preferably when under depression and are bound to get under alcohol abuse in these kind of situations. Hence, some good intervention programs which can help them and cope with situations effectively can be made and implemented especially targeting the introvert population. The study will help to provide effective interventions.

\section{METHODOLOGY}

Objectives:

(1) To examine the attitude of personality type (introvert/extrovert) towards drinking alcohol in patients who have depression.

(2) To examine the attitude of gender (male/female) towards drinking alcohol in patients who have depression.

(3) To study the interaction effect of personality characteristics and gender on attitude towards drinking alcohol in patients who have depression. 


\section{Hypotheses:}

1. Gender (male \&female) will have a significant difference on attitude towards drinking alcohol in people suffering from depression

2. Personality Type (Introversion \&Extroversion) will have a significant difference on attitude towards drinking alcohol in people suffering from depression.

\section{Research Design:}

This research was adopted 2X 2 factorial designs with 2 types of gender (Male and Female) and 2 types of personality characteristics (Introvert and Extrovert).

\begin{tabular}{|l|l|l|l|}
\hline \multicolumn{2}{|l|}{$\begin{array}{l}\text { Male } \\
\text { A1 (47) }\end{array}$} & $\begin{array}{l}\text { Female } \\
\text { A2 (43) }\end{array}$ \\
\hline Introvert & Extrovert & Introvert & Extrovert \\
B1 & B2 & B1 & B2 \\
\hline $\mathrm{N}=23$ & $\mathrm{~N}=24$ & $\mathrm{~N}=19$ & $\mathrm{~N}=24$ \\
\hline
\end{tabular}

A1- means Male

A2- means Female

B1- means Introvert

B2- means Extrovert

\section{Sample Size:}

Ninety patients diagnosed and undergoing treatment for depression were selected from three cities Mumbai, Delhi and Ahmedabad as participants. The participants were in the age of 18 to 30 years. The method of purposive sampling was carried out and further classification was done on the basis of: Gender and personality categories.

\section{Inclusion Criteria}

1. Male and Female Depressive patients diagnosed by Psychiatrist.

2. Age between 18 years to 30 years.

3. No co morbid Psychiatric Illness.

4. Those who can give consent for study.

\section{Exclusion Criteria:}

1. Age below 18 years and above 30 years.

2. Co morbid psychiatric illness with depression.

3. Those who can't give consent for study.

\section{Tools Used:}

In the study self report scales were used for measuring variables personality characteristics and attitude towards alcohol:

\section{Introversion Scale (McCroskey, 1997):}

This introversion scale was developed by McCroskey to be distinct from measures of communication apprehension. An examination of the literature on introversion indicated that other introversions scales have included items that were tapping apprehension about 
communication. Items were drawn from the work of Eysenck, with items which referenced communication excluded. This permits the measurement of introversion without the contamination of communication apprehension items and allows the examination of both introversion and communication apprehension as predictors of communication behaviors independently of each other. The correlations of this measure with the PRCA-24 have been around .30. Alpha reliability estimates have been above .80. Items to measure neuroticism are used as filler items and are not scored with the introversion items.

\section{Attitude towards Alcohol (Bharda \& Girija, 1983):}

Attitude towards drinking Alcohol Scale by B.R Bharda \&P.R Girija(1983) is a Likert scale including 34 items with five ratings on it. Split half reliability coefficient is 0.84 , test retest reliability coefficient is 0.74 . Validity coefficient between attitude and beliefs ranges from 0.28 to 0.38 , construct validity coefficient between attitude and using behaviour is 0.51 .

\section{Procedure:}

Ninety patients diagnosed as depression undergoing treatment were selected from private clinic and Psychiatry OPD's of Delhi, Ahmedabad and Mumbai and then Personality characteristics were measured using scale of introversion by Mc Croskey (1997) on males and females (47 males \& 43 females) then Attitude towards alcohol was measured using scale given by B.R Bharda \& P.R Girija (1983). Scores of all scales were taken and further classified into categories of male introvert, male extrovert, female introvert, female extrovert and SPSS trial version 20.0 for Windows 8 was applied in order to find out results. The Design of the study is a 2 (personality characteristics) $\times 2$ (gender) factorial design because there are two independent variables. The first independent variable Personality Characteristics has two levels, Introversion and Extroversion. The second independent variable Gender has two levels i.e. Male and Female. The study was carried out at Department of Psychology, Maniben Nanavati women's college under Shreemati Nathibai Damodar thackersey University, Mumbai.

\section{Statistical Analysis:}

The statistics and analysis was carried out using SPSS trial version 20.0 for Windows 8. In this study 'F' test was used for statistical analysis. 


\section{RESULT}

Table - 1: Means and Standard Deviation of attitude towards drinking alcohol with reference to Gender and personality Characteristics.

\begin{tabular}{|l|l|l|l|l|}
\hline \multirow{2}{*}{ Gender } & $\begin{array}{l}\text { Personality } \\
\text { characteristics }\end{array}$ & Mean & Std. Deviation & N \\
\hline \multirow{2}{*}{ Male } & Extrovert & 109.5833 & 20.22464 & 24 \\
\cline { 2 - 5 } & Introvert & 123.2609 & 18.91901 & 23 \\
\cline { 2 - 5 } & Total & 116.2766 & 20.57827 & 47 \\
\hline \multirow{2}{*}{ Female } & Extrovert & 92.2917 & 13.25167 & 24 \\
\cline { 2 - 5 } & Introvert & 102.0526 & 18.43449 & 19 \\
\cline { 2 - 5 } & Total & 96.6047 & 16.30533 & 43 \\
\hline Total & Extrovert & 100.9375 & 19.03793 & 48 \\
\cline { 2 - 5 } & Introvert & 113.6667 & 21.34006 & 90 \\
\cline { 2 - 5 } & Total & 106.8778 & 21.02317 & 42 \\
\hline
\end{tabular}

Table - 2: ANOVA summary of attitude towards drinking alcohol with reference to Gender and Personality Characteristics.

\begin{tabular}{|c|c|c|c|c|c|}
\hline Source & $\begin{array}{c}\text { Type III Sum of } \\
\text { Squares }\end{array}$ & df & Mean Square & $\mathbf{F}$ & $\begin{array}{c}\text { Significant } \\
\text { Level }\end{array}$ \\
\hline Gender & 8260.234 & 1 & 8260.234 & 25.890 & $0.01 * *$ \\
\hline $\begin{array}{l}\text { Personality } \\
\text { characteristics (Intro- } \\
\text { Extro) }\end{array}$ & 3061.489 & 1 & 3061.489 & 9.596 & $0.01 * *$ \\
\hline $\begin{array}{l}\text { Gender * personality } \\
\text { characteristics((Intro- } \\
\text { Extro) }\end{array}$ & 85.484 & 1 & 85.484 & .268 & NS \\
\hline Error & 27438.174 & 86 & 319.049 & & \\
\hline Total & 1067393.000 & 90 & & & \\
\hline Corrected Total & 39335.656 & 89 & & & \\
\hline a. R Squared $=.302$ & asted R Squared & & & & \\
\hline
\end{tabular}

${ }^{*} \mathrm{p}<.05,{ }^{* *} \mathrm{p}<.01, \mathrm{NS}=$ Not Significant 
Table-3: Difference between mean score of attitude towards alcohol drinking with reference to gender and personality characteristics.

\begin{tabular}{|l|l|l|l|}
\hline $\begin{array}{l}\text { Independent } \\
\text { Variable }\end{array}$ & $\mathbf{N}$ & Mean (M) & $\begin{array}{l}\text { Difference between } \\
\text { mean }\end{array}$ \\
\hline Male & 47 & 116.42 & 19.25 \\
\hline Female & 43 & 97.17 & \\
\hline Extrovert & 48 & 16.73 & 3.39 \\
\cline { 1 - 2 } Introvert & 42 & 20.12 & \\
\cline { 1 - 2 }
\end{tabular}

When $\mathrm{F}$ test was applied to check the impact of gender on attitude towards drinking alcohol, significant $\mathrm{F}$ value was found. The $\mathrm{F}$ value (Table no.2) was 25.890 which is statistically significant. Table 3 reveals that the mean score of attitude towards drinking alcohol are 116.42 and 97.17 respectively for male and female and the difference between two is 19.25 which is very high and not negligible. Hence the hypothesis 1 was maintain and it was concluded that gender (male \&female) have a significant difference on attitude towards drinking alcohol in people suffering from depression. This provides the idea that male depression has positive attitude towards drinking alcohol whereas female depression has negative attitude towards drinking alcohol.

When F test was applied to check the impact of personality characteristics on attitude towards drinking alcohol, significant $F$ value was found. The $F$ value (Table no.2) was 9.596 which is statistically significant. Table 3 reveals that the mean score of attitude towards drinking alcohol are 16.73 and 20.12 respectively for Extrovert and Introvert and the difference between two is 3.39 which is high and not negligible. Hence the hypothesis 2 was maintained and it was concluded that personality characteristics have a significant difference on attitude towards drinking alcohol in people suffering from depression. This provides the idea that introvert depression patients have positive attitude towards drinking alcohol whereas extrovert depression patients have negative attitude towards drinking alcohol.

When $\mathrm{F}$ test was applied to check the effect of gender and personality characteristics on attitude towards drinking alcohol, no significant $\mathrm{F}$ value was found. The F value (table no.2) is 0.268 which is statistically not significant. So it can be concluded that there was no significant interaction effect of gender and personality characteristics on attitude towards drinking alcohol.

\section{DISCUSSION}

The study found male depression has positive attitude towards drinking alcohol whereas female depression has negative attitude towards drinking alcohol. Supportively, Kumar et al (2013) found Prevalence of alcohol use is high, especially among males. The prevalence of alcohol use was found to be $9.4 \%$. Prevalence was more among males (16.8\%) as compared to that among females (1.3\%). In another study of Azeez et al. (2014) also found out of 1150 students, 304 (26.4\%) consumes alcohol.167 (54.9\%) were males and 137 (45.1\%) were females. Most of 
them were social drinkers. Majority of them consumed 2-3 drinks in one sitting. Tendency of binge drinking is high.

The finding of the study provides the idea that introvert depression patients have positive attitude towards drinking alcohol whereas extrovert depression patients have negative attitude towards drinking alcohol. This may be because introvert people are lonely and in order to overcome loneliness, to entertain themselves and replace the boredom of not having friends, relationships or a family they drink alcohol because alcohol gives temporary euphoric feeling (AdultSocialSkills.com, 2014; alcoholrehab.com, 2015). Similarly, Mushtaq et al. (2014) found loneliness is recognized as a contributing, maintaining and poor prognostic factor in the development of alcohol abuse. Further it is recognized as an essential risk factor in all the stages of alcoholism.

\section{CONCLUSION}

The purposes of the current study was to examine the effect of personality type (introvert/extrovert), gender (male/female) and the interaction effect of personality characteristics and gender on attitude towards drinking alcohol in patients who has depression. The results indicate that personality characteristics had a significant effect on attitude towards alcohol which concludes that introvert depression patients have positive attitude towards drinking alcohol whereas extrovert depression patients have negative attitude towards drinking alcohol. Gender also had a significant effect on attitude towards alcohol which concludes that male depressive patients have positive attitude towards drinking alcohol whereas female depressive patients have negative attitude towards drinking alcohol. It was also found that there was no interaction effect of personality characteristics and gender on attitude towards alcohol.

\section{LIMITATIONS OF THE STUDY}

1. First of all the time duration spent on patients was very short since data collected at one sitting which is the first limiting factor.

2. This sample comprised of individuals from Mumbai, Delhi and Ahmedabad which can be a problem in generalizing for other cities of India.

\section{REFERENCE}

AdultSocialSkills.com (2014). Alcoholism: Lonely people with no friends or social lives drink alone to fight boredum and depression. Retrieved from http://www.adultsocialskills.com/alcohol.htm on 16/12/2015

Alcoholrehab.com. (2015). Introversion and addiction. Retrieved from http://alcoholrehab.com/addiction-articles/introversion-and-addiction/ on 16/12/2015.

Azeez, A., Faizal, A., Ranjan, A., Anjana, R., Anjuna, K.C., Anupam, S., Aparna, M., Kundapur, R., \& Raj, H. (2014). Quantity and prevalence with gender comparison for alcohol consumption among college students. Nitte University Journal of Health Science, 4(2), 105-107. Retrieved from http://nitte.edu.in/journal/June2014/105-107.pdf on 16/12/2015. 
Bharda, B.R. \& Girija, P.R. (1983)Attitude belief and behaviour towards use. In: Current Research in drug abuse in India (Eds) Mohan, D., sethi, H.S. \& Tongue, E., Delhi:

Gemini Printers. Retrieved from http://europepmc.org/backend/ptpmcrender.fcgi?accid=PMC2965839\&blobtype=pdf on 16/12/2015.

Kumar, G. S., Premarajan K.C., Subitha L., Suguna E., Vinayagamoorthy, and Veera Kumar. (2013). Prevalence and Pattern of Alcohol Consumption using Alcohol Use Disorders Identification Test (AUDIT) in Rural Tamil Nadu, India. Journal of Clinical and Diagnostic Research, 7(8), 1637-1639. Retrieved from http://www.ncbi.nlm.nih.gov/pmc/articles/PMC3782918/ on 16/12/2015.

McCroskey (1997). Introversion Scale. Reserved from http://www.jamescmccroskey.com/measures/introversion.htm on 16/12/2015.

Mushtaq, R., Shoib, S., Shah, T., \& Mushtaq, S. (2014). Relationship Between Loneliness, Psychiatric Disorders and Physical Health ? A Review on the Psychological Aspects of Loneliness. Journal of Clinical and Diagnostic Research, 8(9). Retrieved from http://www.ncbi.nlm.nih.gov/pmc/articles/PMC4225959/ on 16/12/2015. 